\title{
Author Correction: Molecular mechanism for the control of virulent Toxoplasma gondii infections in wild-derived mice
}

\author{
Mateo Murillo-León (1) 1,2,3, Urs B. Müller ${ }^{4}$, Ines Zimmermann (1) 1,3, Shishir Singh (10) 1,2,3, Pia Widdershoven 4,5,

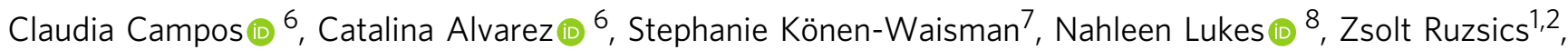 \\ Jonathan C. Howard (10 ${ }^{6}$, Martin Schwemmle ${ }^{1,2} \&$ Tobias Steinfeldt ${ }^{1,2}$
}

Correction to: Nature Communications https://doi.org/10.1038/s41467-019-09200-2, published online 15 March 2019.

The original version of this Article contained an error in the Acknowledgements, which incorrectly omitted the following: 'C.C., C.A., and J.C.H. were supported by the Fundação Calouste Gulbenkian through a grant from the Instituto Gulbenkian de Ciência and by the research infrastructure Congento, project LISBOA-01-0145-FEDER-022170, co-financed by Lisboa Regional Operational Programme (Lisboa 2020), under the Portugal 2020 Partnership Agreement, through the European Regional Development Fund (ERDF), and Foundation for Science and Technology (Portugal).' This has been corrected in both the PDF and HTML versions of the Article.

Published online: 04 April 2019

Open Access This article is licensed under a Creative Commons Attribution 4.0 International License, which permits use, sharing, adaptation, distribution and reproduction in any medium or format, as long as you give appropriate credit to the original author(s) and the source, provide a link to the Creative Commons license, and indicate if changes were made. The images or other third party material in this article are included in the article's Creative Commons license, unless indicated otherwise in a credit line to the material. If material is not included in the article's Creative Commons license and your intended use is not permitted by statutory regulation or exceeds the permitted use, you will need to obtain permission directly from the copyright holder. To view a copy of this license, visit http://creativecommons.org/licenses/by/4.0/.

(c) The Author(s) 2019

\footnotetext{
${ }^{1}$ Institute of Virology, Medical Center University of Freiburg, 79104 Freiburg, Germany. ${ }^{2}$ Faculty of Medicine, University of Freiburg, 79104 Freiburg, Germany. ${ }^{3}$ Faculty of Biology, University of Freiburg, 79104 Freiburg, Germany. ${ }^{4}$ Institute for Genetics, University of Cologne, 50674 Cologne, Germany. ${ }^{5}$ Department of Biology, University of Cologne, 50674 Cologne, Germany. ${ }^{6}$ Fundação Calouste Gulbenkian, Instituto Gulbenkian de Ciencia, $2780-156$ Oeiras, Portugal. ${ }^{7}$ Department for Dermatology and Venereology, University Hospital of Cologne, 50937 Cologne, Germany. ${ }^{8}$ Institute of Immunology, University Hospital Aachen, 52074 Aachen, Germany. These authors contributed equally: Mateo Murillo-León, Urs B. Müller. Correspondence and requests for materials should be addressed to T.S. (email: tobias.steinfeldt@uniklinik-freiburg.de)
} 